\title{
Fluid Inclusions Record Hydrocarbon Charge History in the Shunbei Area, Tarim Basin, NW China
}

\author{
Ziye Lu $\mathbb{D},{ }^{1}$ Yingtao $\mathrm{Li}^{2}{ }^{2}$ Ning Ye $\mathbb{D},{ }^{1}$ Shaonan Zhang, ${ }^{1}$ Chaojin $\mathrm{Lu},{ }^{3}$ Wei Li, ${ }^{1}$ Zhe Cheng, \\ Xiaoqi Ding, ${ }^{4}$ Bei Zhu, ${ }^{1}$ and Baiwen Huang ${ }^{1}$ \\ ${ }^{1}$ School of Geoscience and Technology, Southwest Petroleum University, Chengdu 610500, China \\ ${ }^{2}$ Sinopec Petroleum Exploration and Production Research Institute, Beijing 10083, China \\ ${ }^{3}$ Department of Marine Geosciences, Rosenstiel School of Marine and Atmospheric Science, University of Miami, \\ Miami FL 33149, USA \\ ${ }^{4}$ College of Energy, Chengdu University of Technology, Chengdu 610500, China
}

Correspondence should be addressed to Ning Ye; yn870104@foxmail.com

Received 12 June 2020; Revised 7 August 2020; Accepted 4 September 2020; Published 29 September 2020

Academic Editor: Shengnan Nancy Chen

Copyright (c) 2020 Ziye Lu et al. This is an open access article distributed under the Creative Commons Attribution License, which permits unrestricted use, distribution, and reproduction in any medium, provided the original work is properly cited.

\begin{abstract}
The exploration of deeply buried hydrocarbon is still a challenge for the petroleum geology. The Shunbei area is a newly discovered oil fields, located in the center of the Tarim Basin. The oil is mainly yielded from the Middle-Lower Ordovician carbonate reservoirs with depth $>7000 \mathrm{~m}$ in the Shunbei No. 1 and No. 5 fault zones. Calcite cements filled in vugs (v-calcite) and fractures (f-calcite) are identified in limestones and dolostones of the carbonate reservoirs. F-calcites in the Shunbei No. 1 fault zone trap secondary inclusions in trails, which comprise liquid-dominated biphase aqueous inclusions, liquid-dominated biphase oil inclusions, and/or oil-bearing triphase inclusions. F-calcite and v-calcite in the No. 5 fault zone trap secondary inclusions in trails, which consist of liquid-only monophase aqueous inclusions, liquid-dominated biphase aqueous inclusions, liquid-dominated biphase oil inclusions, liquid-only monophase oil inclusions, and/or oil-bearing triphase inclusions. The ranges of the homogenization temperature $\left(T_{\mathrm{h}}\right)$ and ice-melting temperature $\left(T_{\mathrm{m} \text {-ice }}\right)$ in the Shunbei No. 1 fault zone are, respectively, $130-150^{\circ} \mathrm{C}$ and $-2.1--1.5^{\circ} \mathrm{C}$. The coexistence of liquid-only and liquid-dominated aqueous inclusions in the Shunbei No. 5 fault zone indicates that the aqueous inclusions are trapped at low temperatures. The aqueous inclusions in the Shunbei No. 5 fault zone show a range from -0.4 to $-0.2^{\circ} \mathrm{C}$ in $T_{\mathrm{m} \text {-ice }}$ which is very close to the meteoric fluid. In the context of the burialthermal history and the Cambrian source rock evolution, the charging process of hydrocarbon in the Shunbei No. 1 and No. 5 fault zones corresponds to the Silurian and Middle Ordovician, respectively. Results of fluid inclusions indicate a tightly coupling relationship between the hydrocarbon charging process and fault system evolution in the Shunbei area. This study reveals the application of fluid inclusion under the systemically petrographic constraints to decipher the charging history of hydrocarbon, especially for the deeply buried reservoirs.
\end{abstract}

\section{Introduction}

Fluid inclusions are widely used to the analysis of evolution of diagenetic fluids with the aim to decipher the hydrocarbon charging history [1-6]. Hydrocarbon could be trapped in primary and/or secondary inclusions within diagenetic minerals of reservoirs, when they migrated along pathways of transportation in successions. Coexisting associations of aqueous and petroleum fluid inclusions have a potential to trace the migration and accumulation of petroleum [7-10]. In the con- text of diagenetic parasequences, burial, and geothermal histories, the fluid inclusion can shed light on the main charging state of hydrocarbon $[1,3,5,11,12]$.

During the past five years, the Shunbei Oil Field in the Tarim Basin was newly discovered carbonate reservoirs which were deeply buried to more than $7000 \mathrm{~m}$ in depth (Jiao et al., 2018; [13]) (Figure 1). All the industrial wells are drilled along the strike-slip fault systems, and the pay layers are the Lower-Middle Ordovician carbonate [13, 14] (Figures 1(c) and $1(\mathrm{~d})$ ). Previous studies proposed three episodes of 


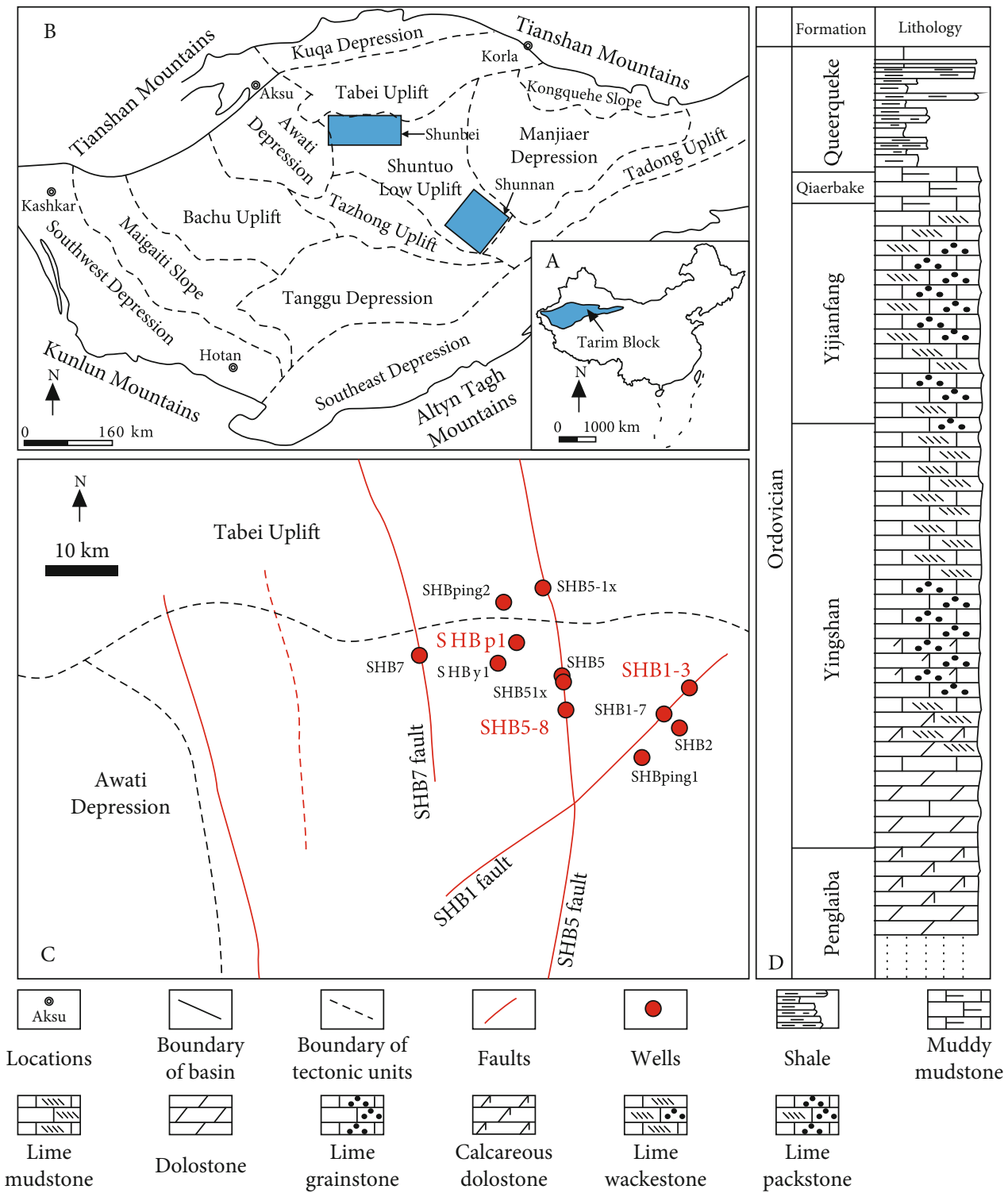

Figure 1: (a) The location of the Tarim Basin in China; (b) the locations of the Shunbei and Shunnan area in the Tarim Basin; (c) the locations of the wells and faults in the Shunbei area; (d) stratigraphy and lithology of the Ordovician succession in the Shunbei area; modified after Deng et al. [17] and Li et al. [13].

hydrocarbon charging events in the Shunbei No. 1 fault zone, including the Late Ordovician-Silurian (the late Caledon to early Hercynian stage), the Carboniferous-Permian (the late Hercynian stage), and the Quaternary (the Himalayan stage) (e.g., [15]). However, the fluid inclusion petrographic data are not published and described in these papers, and the association of measured aqueous inclusions and hydrocarbon inclusions are not clear. These result in that the decoupling relationship between the hydrocarbon charging stages and evolution histories of tectonics and source rock is still a challenge to decipher the accumulation of hydrocarbon in the deeply buried successions [14, 16-21]. Moreover, the Shunbei No. 5 fault zone, in which the structural evolution is different from the Shunbei No. 1 fault zone, lacks of delineation on the hydrocarbon charging process.
In this study, the samples from the Shunbei No. 1 fault zone and the No. 5 fault zone are employed for petrography and fluid inclusion studies. Aims of this study include the following: (1) recognizing the meteoric fluid in fluid inclusions, (2) the hydrocarbon charge events in the Shunbei No. 1 and No. 5 fault zones, and (3) the coupling relationships between the hydrocarbon charging stages and fault evolutions.

\section{Geological Background}

Tarim Basin is one of the petroliferous basins in northwest China. This basin is surrounded by the Tianshan orogen, the Kunlun orogen, and the Altyn orogen (Figures 1(a) and 1(b)) $[22,23]$. The Shunbei Oil Field locates in the north of the Shuntuo Low Uplift that is in the center of the Tarim 
Basin (Figures 1(b) and 1(c)). The Shuntuo Low Uplift is surrounded by the Tabei Uplift to the north, the Manjiaer Depression to the east, the Awati Depression to the west, and the Tazhong Uplift to the south (Figures 1(b) and 1(c)). The Shunbei Oil Field covering the area of $2.8 \times 10^{4}$ $\mathrm{km}^{2}$ was discovered in the deeply buried (>7000 $\mathrm{m}$ in depth) carbonate successions [13, 24] (Figure 1). All the industrial wells are drilled to the Lower-Middle Ordovician successions along the strike-slip fault systems (Figure 1(c)). The petroleum yields are variable depending on the different faults. The yields of well drilling at the No. 1 fault are higher relative to the No. 5 fault, and the oil yielded from the No. 1 fault has higher maturity than those from the No. 5 fault [25].

The target strata for the hydrocarbon exploration is the Yingshan $\left(\mathrm{O}_{1-2} \mathrm{y}\right)$ and Yijianfang $\left(\mathrm{O}_{2} \mathrm{yj}\right)$ formations in the Lower-Middle Ordovician at the Shunbei Oil Field [13]. The overlying fine-grained sediments (e.g., mudstone and shale) of the Queerqueke and Qieerbake formations cap the considered successions (Figure $1(\mathrm{~d})$ ) $[13,24]$. The Upper Cambrian Formation underlying the target succession is expressed by the evaporite and dolostone. In the lower part of the Yingshan Formation, the succession mainly comprises dolo-mudstone and muddy dolo-mudstone. In contrast, the upper part formation consists of mudstone and grainstone (Figure $1(\mathrm{~d})$ ). The lithological association is characterized by the grain-rich sediments (e.g., packstone and grainstone) interbedded with mudstone in the Yijianfang Formation (Figure $1(\mathrm{~d})$ ). The succession of the Yingshan Formation is obviously thicker (about $900 \mathrm{~m}$ ) relative to the Yijianfang Formation (about $150 \mathrm{~m}$ ).

The Yingshan and Yijianfang formations in the Ordovician mainly experienced two uplifted stages at the end of Middle Ordovician and the Silurian-Devonian, respectively $[26,27]$. The denudation associated with subaerial exposure of the Yijianfang Formation can be attributed to the tectonic activity of the Kunlun orogen during the Middle-Late Ordovician. Partly absence of the Silurian-Devonian successions is generated by the Altyn orogen. The Shunbei No. 1 and No. 5 faults are the major strike-slip fault systems in the study area $[13,14,17,18,28,29]$ (Figure 1(c)). The Shunbei No. 5 fault, which continuously contacts to the Tabei Uplift in the north and Tazhong Uplift in the south, shows the trend from NNE to NNW [18] (Figure 1(c)). The Shunbei No. 1 fault is an NE-trending strike-slip fault, which contacts to the Tabei Uplift in the north and is truncated by the Shunbei No. 5 fault in the study area (Figure 1(c)). These two faults show the different tectonic processes based on the $3 \mathrm{D}$ seismic interpretation $[14,18]$. As regarded to the Shunbei No. 5 fault, three active stages, respectively, correspond to the middle (Middle Ordovician), late Caledon stages (Early Silurian), and the Hercynian stage (Carboniferous-Permian). In contrast, the Shunbei No. 1 fault only shows two major active stages including the late Caledon stage (Early Silurian) and Hercynian orogen (Carboniferous-Permian) [14].

Previous studies indicated that the oil produced in the Shunbei area may be generated from the Lower Cambrian shales $[19,20,25,30]$. Depending on the apatite and zircon (uranium-thorium)/helium ages, apatite fission tracks, and vitrinite reflectance data, the source rock is considered to remain in the mature stage $\left(0.5 \%<R_{\text {equ }}<1.3 \%\right)$ by the end of the Ordovician and evolves to the gas and dry gas stage $\left(1.3 \%<R_{\text {equ }}\right)$ by the end of the Permian [21] (Figures 1(b) and $1(\mathrm{c}))$. Moreover, the 1-D burial-thermal history of the Ordovician succession in the Shunbei area (well SHB1-3) was established by Wang et al. [15] using the software BasinMod. The burial temperatures proposed by Wang et al. [27] are consistent with the thermal history reconstruction of the Tarim Basin based on vitrinite reflectance and apatite fission track data $[16,21,31]$. The geothermal gradients listed in Wang et al. [15] are in accordance with those proposed by Li et al. [31]. The erosional thickness during the Devonian uplift in Wang et al. [27] of $900 \mathrm{~m}$ is also consistent with that estimated by Liu et al. [26]. Therefore, the burial-thermal history from Wang et al. [15] will be used in this paper for further discussion.

\section{Methods}

Two hundred and twelve meters of cores in the Ordovician Yingshan and Yijianfang formations from 12 wells, which are drilled in the Shunbei No. 1 and No. 5 faults and the west of No. 5 fault (Figure 1(c)), are observed in this research. Two hundred and forty polished thin sections and casting thin sections with thickness of $30 \mu \mathrm{m}$ are employed for petrographic research. More than 100 doubly polished thin sections with thickness of approximately $100 \mu \mathrm{m}$ are employed for fluid inclusion petrographic research, and 6 of them are selected for further fluid inclusion microthermometric work.

The fluid inclusion microthermometry was performed at Key Lab of Sichuan Province Natural Gas Geology, Southwest Petroleum University. The UV epifluorescence equipment is used to detect the oil inclusions. Fluid inclusion microthermometry was performed using a Linkam THMGS600 heating-freezing stage, which was calibrated using synthetic fluid inclusions with known compositions. The cycling technique mentioned in Goldstein and Reynolds [2] was used for the measurement of homogenization temperatures and ice final melting temperatures in this study. The heating, cooling, and/or cycling intervals are $0.1^{\circ} \mathrm{C}$ for ice-melting temperatures $\left(T_{\mathrm{m} \text {-ice }}\right), 1^{\circ} \mathrm{C}$ for hydrohalitemelting temperatures $\left(T_{\mathrm{m}-\mathrm{HH}}\right)$, and $5^{\circ} \mathrm{C}$ for homogenization temperatures $\left(T_{\mathrm{h}}\right)$ and metastable freezing temperatures $\left(T_{\mathrm{f}}\right.$ ). Take an example, the $T_{\mathrm{h}}$ value of $135^{\circ} \mathrm{C}$ means the fluid inclusion homogenized to liquid phase in the interval of $(130,135)\left(130^{\circ} \mathrm{C}<T_{\mathrm{h}} \leq 135^{\circ} \mathrm{C}\right)$. Some of the liquid-only aqueous inclusions were heated in a muffle furnace at $250^{\circ} \mathrm{C}$ for more than 6 hours, in aim to stretch the inclusions and get the $T_{\mathrm{m} \text {-ice }}$ values [2]. The compositions and salinities of the fluid inclusions were approximated by the $\mathrm{H}_{2} \mathrm{O}-\mathrm{NaCl}$ system in this research [32-34]. The program by SteeleMacInnis et al. [34] was used to calculate the salinity of the inclusions that the last melting phase is hydrohalite or ice in low temperatures.

Calcite is the soft mineral, and aqueous fluid inclusions in calcite are easily reequilibrated during burial diagenesis [3539]. Therefore, the concept of the fluid inclusion assemblage (FIA) [2] is used to evaluate the validation of the fluid inclusion homogenization temperatures in this research. Fluid 
inclusions in the same FIA are considered as trapping simultaneously [2, 40]. The FIA is described as "consistent" when fluid inclusions within the FIA with variable sizes and shapes have $T_{\mathrm{h}}$ variation less than $10^{\circ} \mathrm{C}$, as "moderately consistent" when inclusions have $T_{\mathrm{h}}$ variation of $10-15^{\circ} \mathrm{C}$, and as "inconsistent" when inclusions have $T_{\mathrm{h}}$ variation larger than $15^{\circ} \mathrm{C}$. The moderately consistent and inconsistent FIAs suggest that the inclusions in the FIAs experienced moderate and significant reequilibration, respectively [2].

\section{Petrography and Paragenesis}

Cements in the Yingshan dolostones and the Yijianfang limestones are mostly calcites filling in the fractures (f-calcite) and vugs (v-calcite) (Figures 2(a) and 2(b)). Calcite cements occur as blocky crystals ranging from 0.25 to 1 millimeter in size (Figures 3(a)-3(c)). In the limestone, the fractures crosscut the vugs (Figure 3(a)), suggesting that $\mathrm{f}$-calcite postdates $\mathrm{v}$-calcite. Bitumen and cryptocrystalline silica minerals are identified in the fractures which are partly filled by f-calcites (Figures 3(b) and 3(c)). This suggests that bitumen and cryptocrystalline silica minerals postdate f-calcite.

In dolostones of the Yingshan Formation, calcite cements are recognized in fractures (f-calcite) and intercrystalline pores (v-calcite) (Figure 2(c)). Calcite cements occur as blocky crystals with the range from 0.25 to 1 millimeter in crystal sizes. In the well SHBp1, the medium-crystalline, planar-e dolomites (MD) stack loosely (Figure 3(d)). Vcalcite filling the intercrystalline pores and replacing $\mathrm{MD}$ suggest that $\mathrm{v}$-calcite postdates dolomitization (Figure 3(e)). High-amplitude stylolite crosscut MD and partly dissolved v-calcite (Figures 3(f) and 3(g)) suggest that highamplitude stylolites postdate $\mathrm{v}$-calcite and predate the calcite dissolution. Authigenic quartz with crystal size less than $50 \mu \mathrm{m}$ is found in the intercrystalline pores of $\mathrm{MD}$ (Figure 3(h)).

\section{Fluid Inclusion Studies}

5.1. Fluid Inclusion Petrography. Fluid inclusions were studied in calcite cements. Based on phase assemblages present at room temperature and fluid types (oil or aqueous fluid), five types of fluid inclusions were identified: (1) liquiddominated biphase (liquid + vapor) aqueous inclusions, with vapor percentage $<50 \%$; (2) liquid-only monophase aqueous inclusions; (3) liquid-only monophase oil inclusions; (4) liquid-dominated biphase (liquid + vapor) oil inclusions, with vapor percentage $<50 \%$; and (5) oil-bearing triphase (aqueous liquid + oil + vapor) inclusions. All the inclusions occur in trails that crosscut crystals, which are considered to be of secondary origin (Figure 4 ).

The types and coexistence of fluid inclusions show in Table 1. F-calcite in samples from the Shunbei No. 1 fault (e.g., well SHB1-3) contains fluid inclusions in trails (trails CT1). The inclusions in CT1 comprise the liquiddominated aqueous inclusions, liquid-dominated biphase oil inclusions, and/or oil-bearing triphase inclusions (Figures 4(a) and 4(b)). More petrographic evidence about the association of aqueous and oil inclusions is shown in ESM 1. F-calcite and v-calcite cements in samples from the Shunbei No. 5 fault (e.g., well SHB5-8) contain fluid inclusions in trails (trails CT5). The inclusions in CT5 comprise the liquid-dominated aqueous inclusions, liquid-only aqueous inclusions, liquid-dominated oil inclusions, liquid-only oil inclusions, and/or oil-bearing triphase inclusions (Figures 4(c)-4(f)). More petrographical evidence is shown in ESM 1. F-calcite in the samples from the west of the Shunbei No. 5 fault (e.g., well SHBp1) contains fluid inclusions in trails (trails CTp1-f). The inclusions in CTp1-f comprise the liquid-dominated aqueous inclusions with relatively consistent vapor/liquid ratios and liquid-only aqueous inclusions (Figure 4(g)). V-calcite cements in the samples from the west of the Shunbei No. 5 fault contain fluid inclusions in trails (trails CTp1-v). The inclusions in CTp1-v comprise the liquid-dominated aqueous inclusions with inconsistent vapor/liquid ratios and liquid-only aqueous inclusions (Figure 4(f)). Oil inclusions were not found in the samples from the west of the Shunbei No. 5 fault.

5.2. Fluid Inclusion Microthermometry. Fluid inclusion assemblages (FIAs) are identified depending on the fluid inclusion petrographic works. Because all the measured inclusions are distributed in trails, fluid inclusions distributed in the same trail are considered to be belong to a FIA. FIAs with aqueous and oil inclusions coexisted are shown in ESM 1 and Figures 4(a)-4(d). A total of 160 secondary aqueous fluid inclusions were measured for homogenization temperatures $\left(T_{\mathrm{h}}\right)$, ice-melting temperatures $\left(T_{\mathrm{m} \text {-ice }}\right)$, hydrohalite-melting temperatures $\left(T_{\mathrm{m}-\mathrm{HH}}\right)$, and/or metastable freezing temperatures $\left(T_{\mathrm{f}}\right)$. All the microthermometric data are shown in Table 2 . The $T_{\mathrm{h}}$ and/or $T_{\mathrm{m} \text {-ice }}$ values are illustrated in Figures 5-8. Furthermore, the petrographic photos showing FIAs in CT1 and CT5 (Figures 5-7) are shown in ESM 1, and the detailed microthermometric data of CT1 and CT5 can be found in ESM 2 and ESM 3, respectively.

The liquid-dominated biphase aqueous inclusions in CT1 show moderately consistent microthermometric data (Figure 5, ESM 2). The aqueous inclusions in CT1 have $T_{\mathrm{f}}$ values of $-45--40^{\circ} \mathrm{C}$ (ESM 2), and the last melting phase of them during low temperatures is ice. The aqueous inclusions in five FIAs with aqueous inclusions and oil inclusions (or oil-bearing inclusions) coexisted have $T_{\mathrm{h}}$ values of $135-150^{\circ} \mathrm{C}$, and $T_{m \text {-ice }}$ values of $-2.1--1.5^{\circ} \mathrm{C}$ with salinities of $2.5-3.6 \mathrm{wt} \% \mathrm{NaCl}$ (Figures 5 and 6, ESM 1, ESM 2). The aqueous inclusions in two FIAs with only aqueous inclusions have $T_{\mathrm{h}}$ values of $130-150^{\circ} \mathrm{C}$ and $T_{\mathrm{m} \text {-ice }}$ values of $-2.0--1.5^{\circ} \mathrm{C}$ with salinities of $2.5-3.5 \mathrm{wt} \% \mathrm{NaCl}$ (Figures 5 and 6, ESM 2).

Vapors of the liquid-only aqueous inclusions in CT5 and CTp1-v are commonly not appeared during supercooling (to $-180^{\circ} \mathrm{C}$ ) and have $T_{\mathrm{f}}$ values of $-45--40^{\circ} \mathrm{C}$ (ESM 3). The liquid-dominated biphase aqueous inclusions that are coexisted with the liquid-only aqueous inclusions in two FIAs were measured for $T_{\mathrm{h}}$ values, showing inconsistent $T_{\mathrm{h}}$ values that range from $85^{\circ} \mathrm{C}$ to $110^{\circ} \mathrm{C}$ and $65^{\circ} \mathrm{C}$ to higher than $150^{\circ} \mathrm{C}$, respectively (ESM 3 ). The last melting phase of the liquid- 


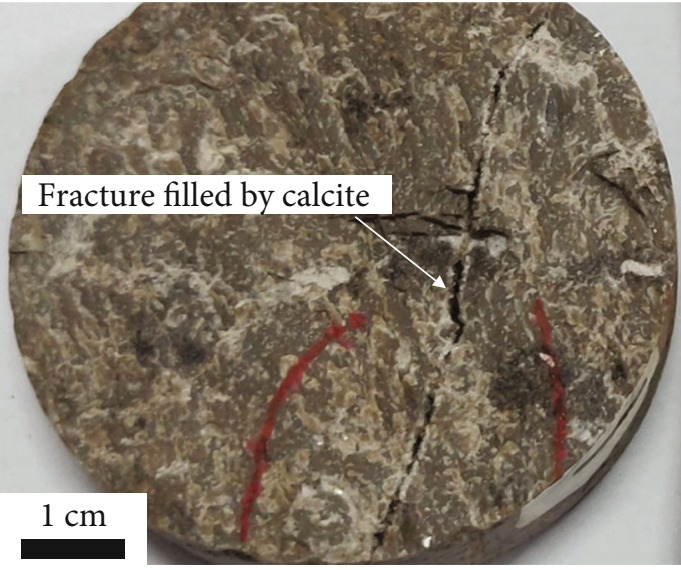

(a)

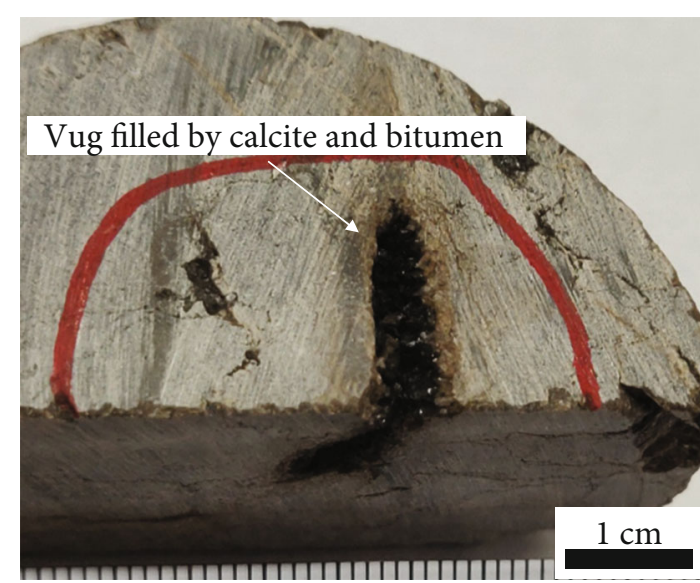

(b)

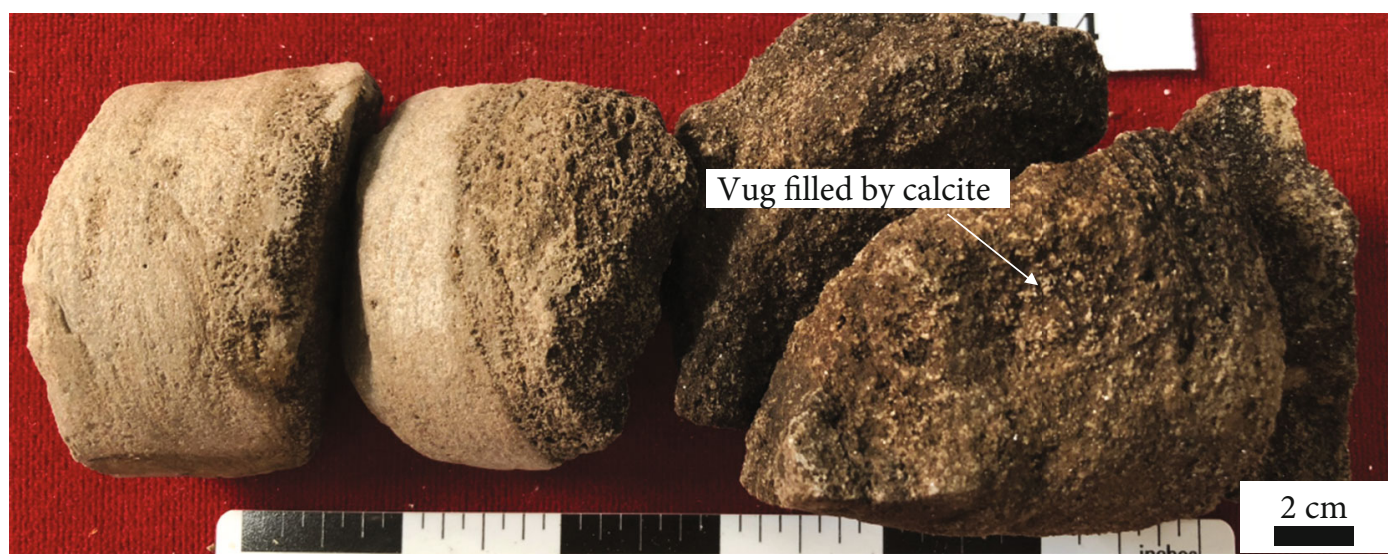

(c)

FIGURE 2: Core photos showing various petrography. (a) Core photo (SHB5-8; 7678.5-7678.7 m; $\mathrm{O}_{2} \mathrm{yj}$ ) showing the fracture filled by calcite. (b) Core photo (SN5-1x; 7481.4-7481.6; $\mathrm{O}_{2} \mathrm{yj}$ ) showing the vug filled by calcite and bitumen. (c) Core photo (SHBp1; 8450.6-8450.8 $\mathrm{m}$; $\mathrm{O}_{1-2} \mathrm{Y}$ ) showing the porous $\mathrm{O}_{1-2} \mathrm{y}$ dolostone.

dominated biphase and liquid-only aqueous inclusions during low temperatures is ice, and the $T_{\mathrm{m} \text {-ice }}$ values range from $-3.8^{\circ} \mathrm{C}$ to $-0.2^{\circ} \mathrm{C}$, with salinities of $0-6.3 \mathrm{wt} \% \mathrm{NaCl}$ (Figure 7 , Table 2, ESM 3). Six FIAs of all the fifteen FIAs in CT5 have coexisted with oil inclusions or oil-bearing inclusions (Figures 4(c) and 4(d), ESM 1, ESM 3), and 76\% of the $T_{\text {m-ice }}$ values fall into the range of $-0.4^{\circ} \mathrm{C}$ to $-0.2^{\circ} \mathrm{C}$, with salinities of $0-0.4 \mathrm{wt} \% \mathrm{NaCl}$ (Figure 7 ).

Vapors of the liquid-only aqueous inclusions in CTp1-f appeared during supercooling (to $-180^{\circ} \mathrm{C}$ ) once or several times. The liquid-only and liquid-dominated biphase aqueous inclusions showed consistent $T_{\mathrm{h}}$ values, and the FIAs in CTp1-f have $T_{\mathrm{h}}$ values of $100-125^{\circ} \mathrm{C}$ (Figure 8, Table 2, ESM 2). The last melt phase of the inclusions in CTp1-f is hydrohalite, and the $T_{\mathrm{m}-\mathrm{HH}}$ values are $-11^{\circ} \mathrm{C}(n=13)$, with a salinity of $25.0 \mathrm{wt} \% \mathrm{NaCl}$ (Table 2, ESM 2).

\section{Discussions}

6.1. Interpretation of Fluid Inclusion Data. In order to decipher the hydrocarbon charge history using aqueous fluid inclusion data, the coexisting of aqueous inclusions and oil inclusions are emphasized in this study (ESM 1 and Figure 4). When oil migrated in the pathway and/or in the reservoir, the oil and pore waters are immiscible and coexisted $[10,41]$. Fluid inclusions in a trail may trap the oil phase, the aqueous fluid phase, or both of them. Inclusions within a trail trapping oil phase are shown in Figures 3(c) and $3(\mathrm{~d})$, and those trapping both two phases are shown in Figures 3(a) and 3(b) and ESM 1. The aqueous inclusions in 5 FIAs with aqueous and oil inclusions coexisted (Figures 3(a) and 3(b), ESM 1) and 2 FIAs with only aqueous inclusions show very similar $T_{\mathrm{h}}$ and $T_{\mathrm{m} \text {-ice }}$ ranges (Figures 5 and 6, ESM 2), indicating the aqueous inclusions in the 2 FIAs may be the endmember trapping the aqueous fluid phase. Therefore, the data from 2 FIAs with only aqueous inclusions are also used to constrain the fluid temperatures when the oil migrated. The aqueous inclusions in CT1 consist of liquid-dominated biphase aqueous inclusions, which show moderately consistent $T_{\mathrm{h}}$ values and very similar $T_{\text {m-ice }}$ values, indicating that fluid inclusions in CT1 are trapped in high-temperature (higher than $40-50^{\circ} \mathrm{C}$ ) environment [2]. The $T_{\mathrm{m} \text {-ice }}$ values of $-2.1--1.5^{\circ} \mathrm{C}$ are similar to that of the modern seawater $\left(-1.9^{\circ} \mathrm{C}\right)$ (Figure 6), implying the 


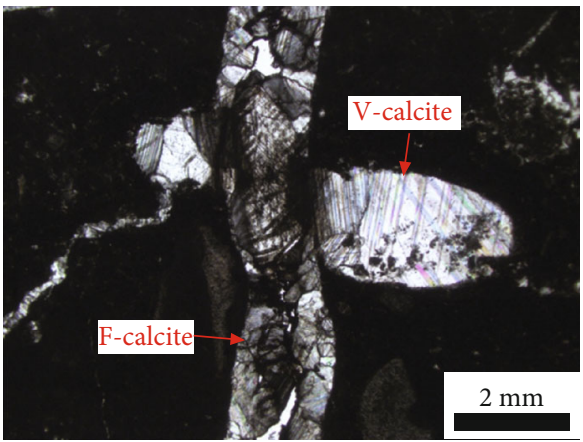

(a)

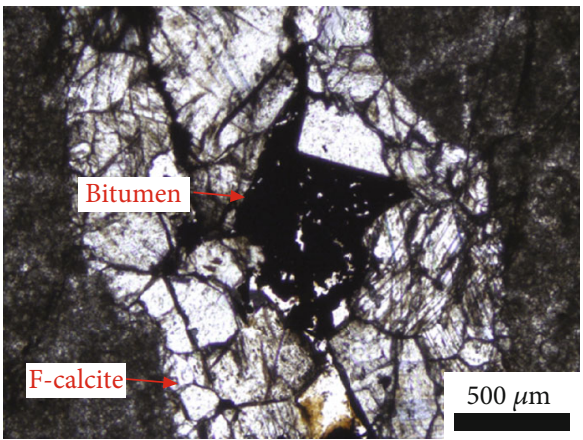

(c)

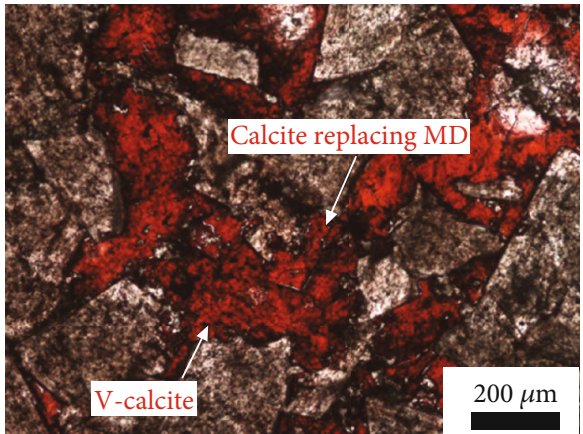

(e)

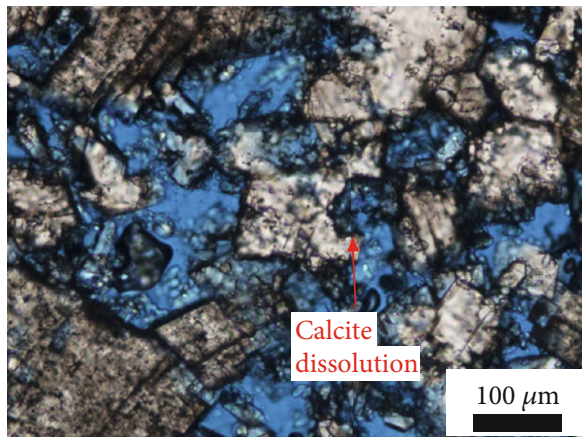

(g)

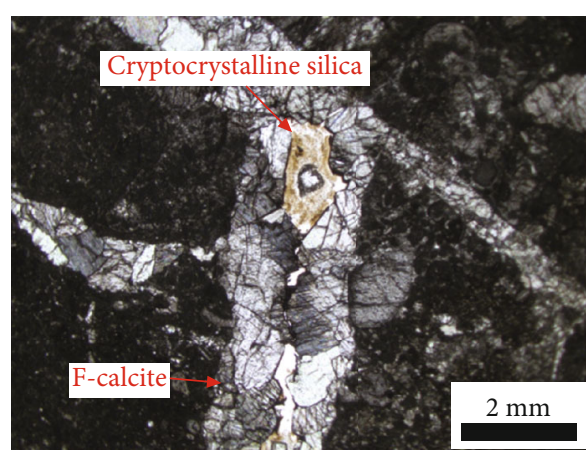

(b)

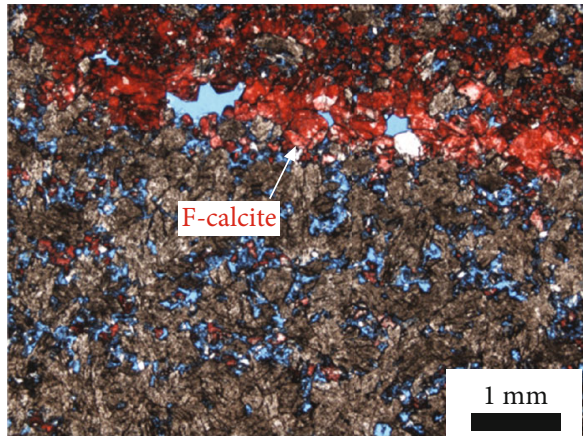

(d)

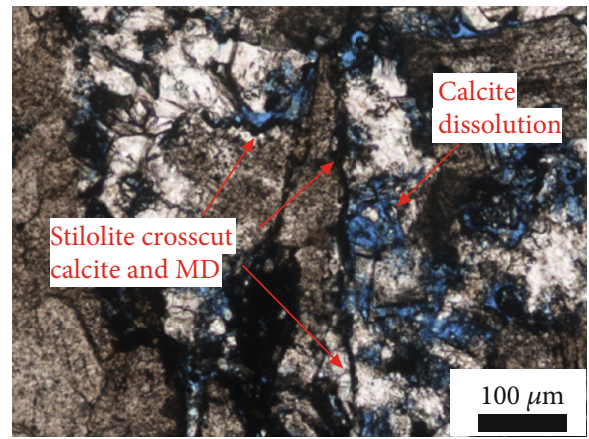

(f)

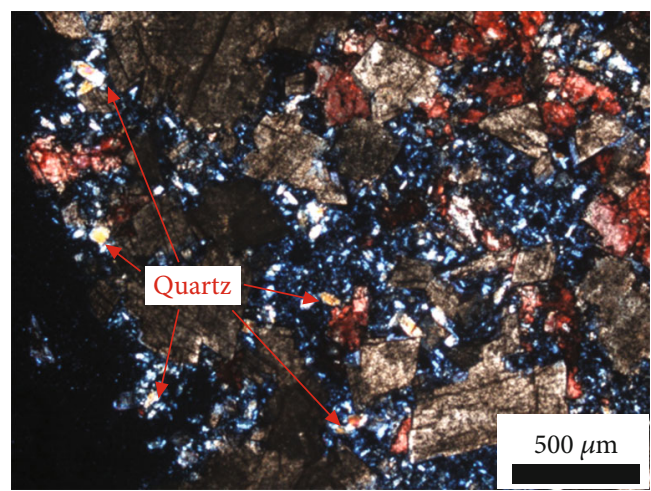

(h)

FIGURE 3: Photomicrographs showing varied occurrences of calcite cements and their relationships. (a) F-calcite crosscutting v-calcite; plane polarized light (SHB5-8-1; 7678.6 m; $\mathrm{O}_{2}$ yj). (b) Cryptocrystalline silica filling the rest space left by f-calcite; plane polarized light (SHB5-8-3; $7679.3 \mathrm{~m} ; \mathrm{O}_{2} \mathrm{yj}$ ). (c) Bitumen filling the rest space left by f-calcite; plane polarized light (SHB5-8-1; 7679.3 m; $\mathrm{O}_{2} \mathrm{yj}$ ). (d) F-calcite and mediumcrystalline, planar-e dolomites (MD); plane polarized light, blue glue, stained by ARS (SHBP1; $8450.6 \mathrm{~m}$; $O_{1-2} \mathrm{y}$ ). (e) V-calcite filling the intercrystalline pores of MD and replacing MD; plane polarized light, stained by ARS (SHBp1; 8451.2 m; $O_{1-2}$ y). (f) High-amplitude stylolites crosscutting MD and v-calcite and v-calcite dissolution; plane polarized light, blue glue (SHBp1; 8450.6 m; $O_{1-2} \mathrm{y}$ ). (g) V-calcite dissolution; plane polarized light, blue glue (SHBp1; $8450.6 \mathrm{~m} ; O_{1-2} y$ ). (h) Quartz filling the intercrystalline pores of MD; crossed polarized light, stained by ARS (SHBP1; $8450.8 \mathrm{~m} ; \mathrm{O}_{1-2} y$ ). 


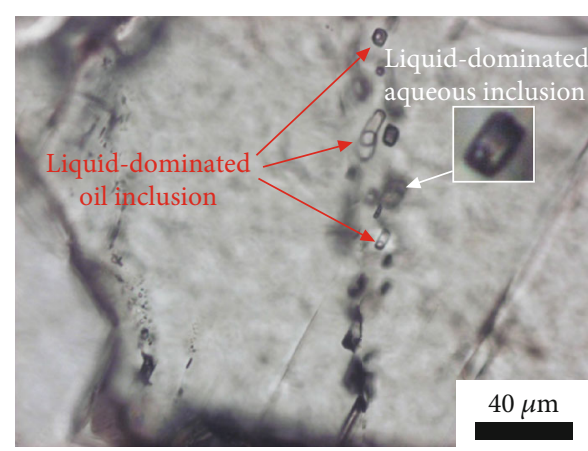

(a)

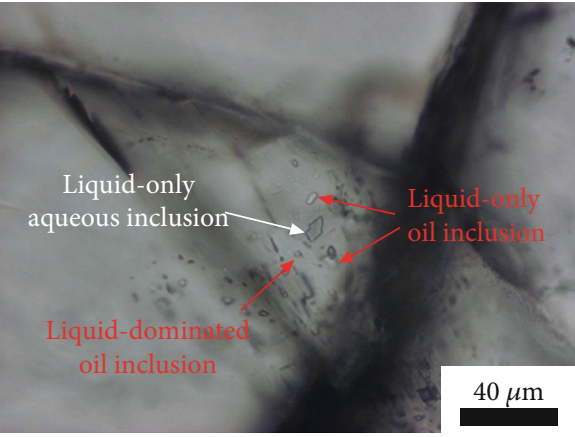

(c)

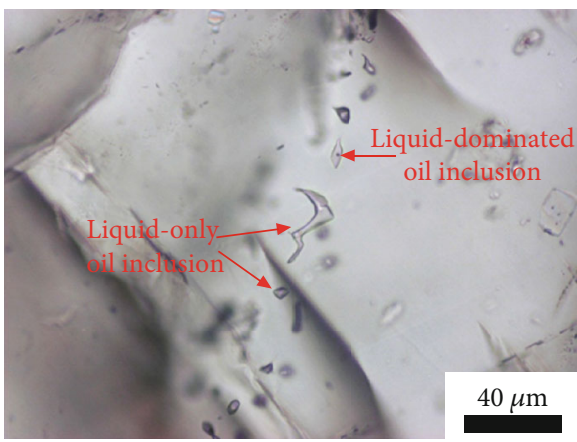

(e)

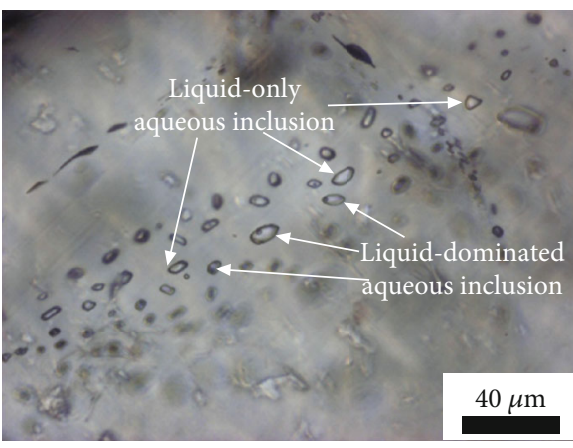

(g)

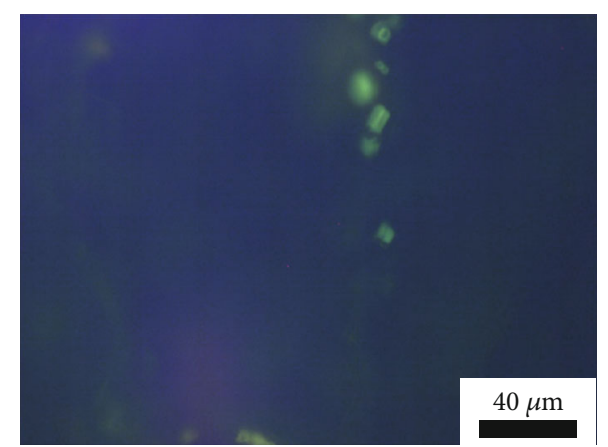

(b)

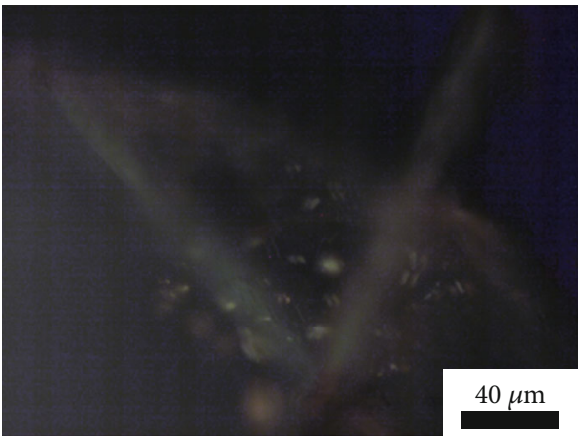

(d)

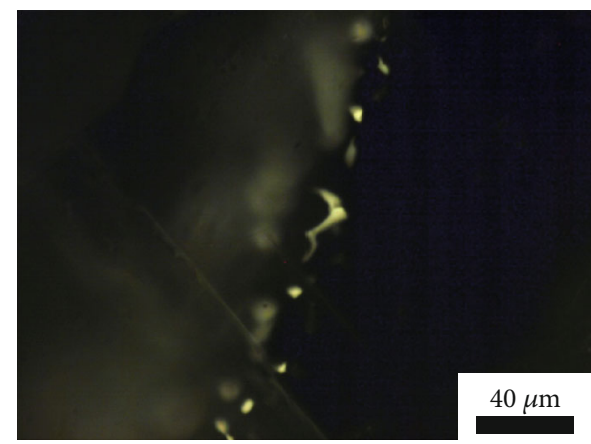

(f)

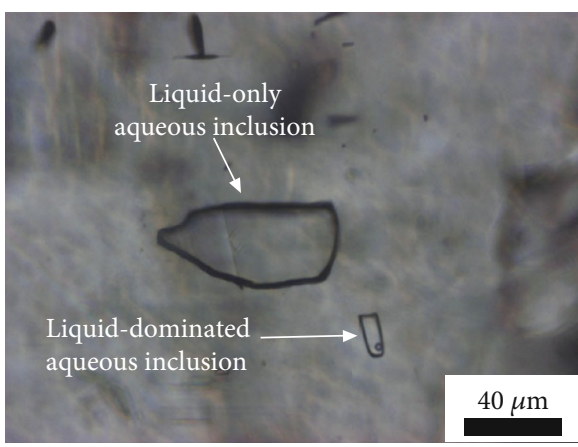

(h)

FIGURE 4: The petrographic characteristics of fluid inclusions. (a, b) Liquid-dominated aqueous inclusions and liquid-dominated biphase oil inclusions coexisting in trails CT1; plane polarized light and fluorescent light (SHB1-3; 7269.1 m; $\mathrm{O}_{2} \mathrm{yj}$ ). (c, d) Liquid-only aqueous inclusions, liquid-only oil inclusions, and liquid-dominated biphase oil inclusions coexisting in trails CT5; plane polarized light and fluorescent light (SHB5-8; $7678.8 \mathrm{~m} ; \mathrm{O}_{2} \mathrm{yj}$ ). (e, f) Liquid-only oil inclusions and liquid-dominated biphase oil inclusions coexisting in trails CT5; plane polarized light and fluorescent light (SHB5-8; 7679.3 m; $\mathrm{O}_{2} \mathrm{yj}$ ). (g) Liquid-only aqueous inclusions and liquid-dominated biphase aqueous inclusions coexisting in trails CTp1-f; plane polarized light (SHBp1; $\left.8450.1 \mathrm{~m} ; \mathrm{O}_{1-2} \mathrm{y}\right)$. (h) Liquid-only aqueous inclusions and liquiddominated biphase aqueous inclusions coexisting in trails CTp1-v; plane polarized light (SHBp1; $8450.1 \mathrm{~m} ; O_{1-2} \mathrm{y}$ ). 
TABLE 1: Fluid inclusion occurrence and coexistence. The blue circles and red circles represent the aqueous inclusions and oil inclusions, respectively. The black circles represent the vapors in inclusions.

\begin{tabular}{|c|c|c|c|c|}
\hline Trails & Mineral & Well & Inclusion types & Sketch of inclusions \\
\hline CT1 & f-calcite & SHB1-3 & $\begin{array}{l}\text { Liquid-dominated aqueous inclusions, } \\
\text { liquid-dominated biphase oil inclusions, } \\
\text { and/or oil-bearing triphase inclusions }\end{array}$ & \\
\hline CT5 & f-calcite and v-calcite & SHB5-8 & $\begin{array}{l}\text { Liquid-dominated aqueous inclusions, } \\
\text { liquid-only aqueous inclusions, } \\
\text { liquid-dominated oil inclusions, } \\
\text { liquid-only oil inclusions, } \\
\text { and/or oil-bearing triphase inclusions }\end{array}$ & \\
\hline CTp1-f & f-calcite & SHBP1 & Liquid-dominated aqueous inclusions & \\
\hline CTp1-v & v-calcite & SHBP1 & and vapor-only aqueous inclusions & \\
\hline
\end{tabular}

TABle 2: Fluid inclusion microthermometric data.

\begin{tabular}{|c|c|c|c|c|c|}
\hline Trails & Inclusion types & $\begin{array}{l}\text { Homogenization } \\
\text { temperatures }\left({ }^{\circ} \mathrm{C}\right)\end{array}$ & $\begin{array}{l}\text { Metastable freezing } \\
\text { temperatures }\left({ }^{\circ} \mathrm{C}\right)\end{array}$ & $\begin{array}{l}\text { Ice final melting } \\
\text { temperatures }\left({ }^{\circ} \mathrm{C}\right)\end{array}$ & $\begin{array}{l}\text { Hydrohalite final melting } \\
\text { temperatures }\left({ }^{\circ} \mathrm{C}\right)\end{array}$ \\
\hline CT1 & $\begin{array}{l}\text { Liquid-dominated } \\
\text { biphase aqueous }\end{array}$ & $130-150$ & $-45--40$ & $-2.1--1.6$ & \\
\hline \multirow{2}{*}{ CT5 } & $\begin{array}{l}\text { Liquid-dominated } \\
\text { biphase aqueous }\end{array}$ & $65->150$ & $-45--40$ & \multirow{2}{*}{$-3.8--0.2$} & \\
\hline & $\begin{array}{c}\text { Liquid-only } \\
\text { monophase aqueous }\end{array}$ & & $-45--40$ & & \\
\hline \multirow{2}{*}{$\begin{array}{l}\text { CTp1- } \\
\mathrm{v}\end{array}$} & $\begin{array}{l}\text { Liquid-dominated } \\
\text { biphase aqueous }\end{array}$ & & $-45--40$ & \multirow{3}{*}{$-0.9--0.2$} & \\
\hline & $\begin{array}{c}\text { Liquid-only } \\
\text { monophase aqueous }\end{array}$ & & $-45--40$ & & \\
\hline $\begin{array}{l}\text { CTp1- } \\
\mathrm{f}\end{array}$ & $\begin{array}{l}\text { Liquid-dominated } \\
\text { biphase aqueous }\end{array}$ & $100-125$ & $-80--75$ & & -11 \\
\hline
\end{tabular}

aqueous fluid may be the pore water derived from seawater $[7,42]$. The moderately consistent FIAs (Figures 5 and 6) suggest that the inclusions may experience moderate reequilibration during burial diagenesis, especially the stretching (Figure 6) $[2,37]$. Therefore, the lowest $T_{\mathrm{h}}$ value of $130^{\circ} \mathrm{C}$ (inclusions homogenized at $125-130^{\circ} \mathrm{C}$ ) may be closer to the real homogenization temperature and will be used for further discussion.

The aqueous fluid inclusions in CT5 and CTp1-v comprise liquid-only monophase and liquid-dominated biphase aqueous inclusions. Both types of the inclusions have $T_{\mathrm{f}}$ values of $-45--40^{\circ} \mathrm{C}$, indicating that they have low salinities [43]. Vapors of the liquid-only inclusions are commonly not appeared during supercooling, and the coexisted liquiddominated inclusions have inconsistent $T_{\mathrm{h}}$ values (ESM 3). Those can be interpreted that the liquid-only inclusions were trapped in low-temperature $\left(<40-50^{\circ} \mathrm{C}\right)$ environment, but the coexisted liquid-dominated inclusions result from reequilibration during burial diagenesis [2].
The aqueous fluid inclusions in CTp1-f comprise liquidonly monophase and liquid-dominated biphase aqueous inclusions. Vapors of the liquid-only inclusions appeared during supercooling, and the liquid-only inclusions show similar $T_{\mathrm{h}}$ values to those of the coexisted liquid-dominated inclusions. Therefore, the liquid-only aqueous inclusions may result from vapor nucleating metastability. The metastability may be due to the high salinities of the inclusion fluids, which is consistent to the high salinity of $25.0 \mathrm{wt} \% \mathrm{NaCl}$ (Table 2 and ESM 3). These fluid inclusions are of secondary origin, and they are not coexisted with hydrocarbon inclusions. Therefore, they cannot represent for the information of mineral precipitation or hydrocarbon charge. In addition, the high salinities are generally attributed to the dissolution of salt [44].

6.2. Meteoric Water. The meteoric water commonly has a low salinity with nearly zero salt content, which shows an ice final melting temperature close to $0^{\circ} \mathrm{C}$ in fluid inclusions $[2,45]$. In 


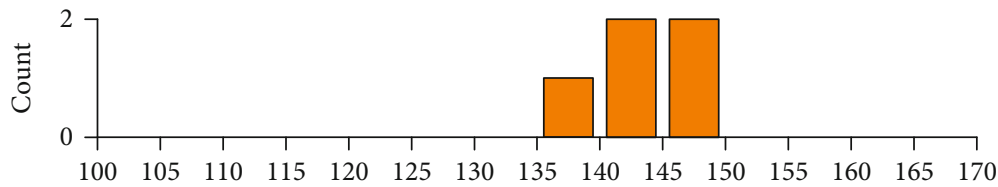

FIA $1, n=5$

Aqueous inclusions coexisted with oil inclusions

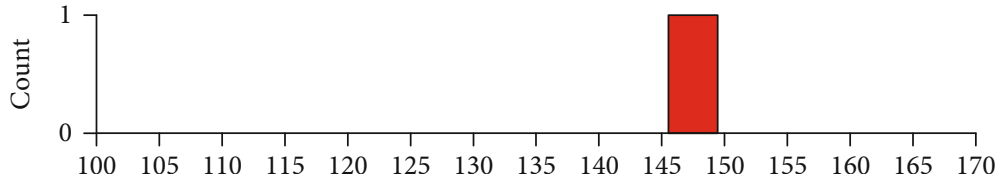

FIA2, $n=1$

Aqueous inclusions coexisted with oil-bearing triphase inclusions
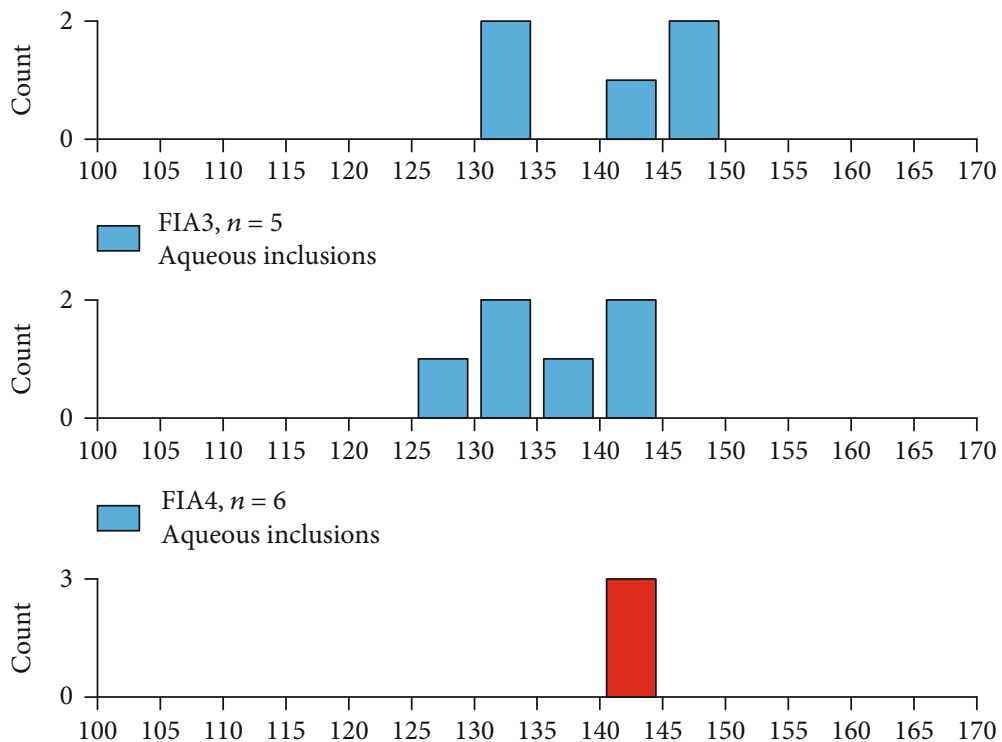

FIA $5, n=3$

Aqueous inclusions coexisted with oil inclusions

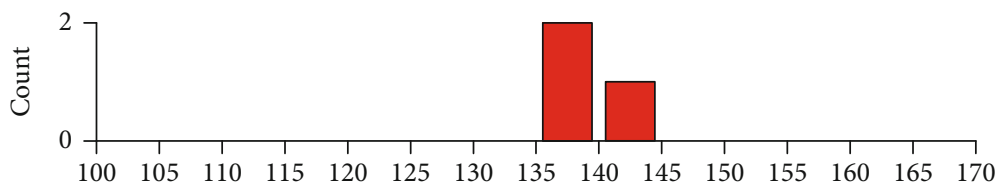

FIA6, $n=3$

Aqueous inclusions coexisted with oil inclusions

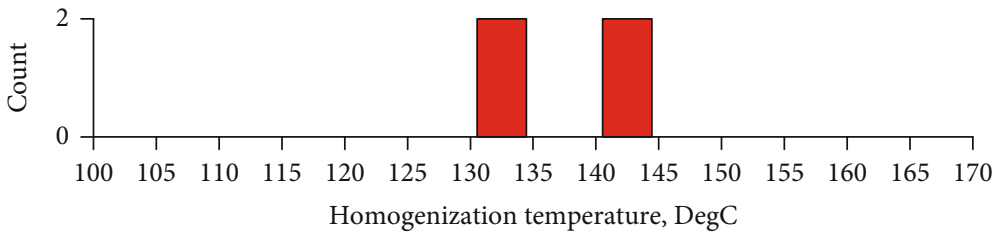

FIA7, $n=4$

Aqueous inclusions coexisted with oil inclusions

FIgURE 5: Histograms of homogenization temperatures of fluid inclusions in each FIA (fluid inclusion assemblage) in CT1. The petrographic evidence that supports the FIAs can be found in ESM 1 and Figure 4.

this study, the liquid-only and liquid-dominated inclusions in CT5 and CTp1-v show $T_{\text {m-ice }}$ values of mainly $-0.4--$ $0.2^{\circ} \mathrm{C}$ (Figure 7), which suggests that the inclusions may trap paleo-meteoric waters and those inclusions with high salin- ities may result from fluid inclusion reequilibration or slightly mixing of meteoric water and pore water ([2]; Zhaoqi [45]). The meteoric water is detected by fluid inclusions in CT5 (well SHB5-8, the Shunbei No. 5 fault zone) and 


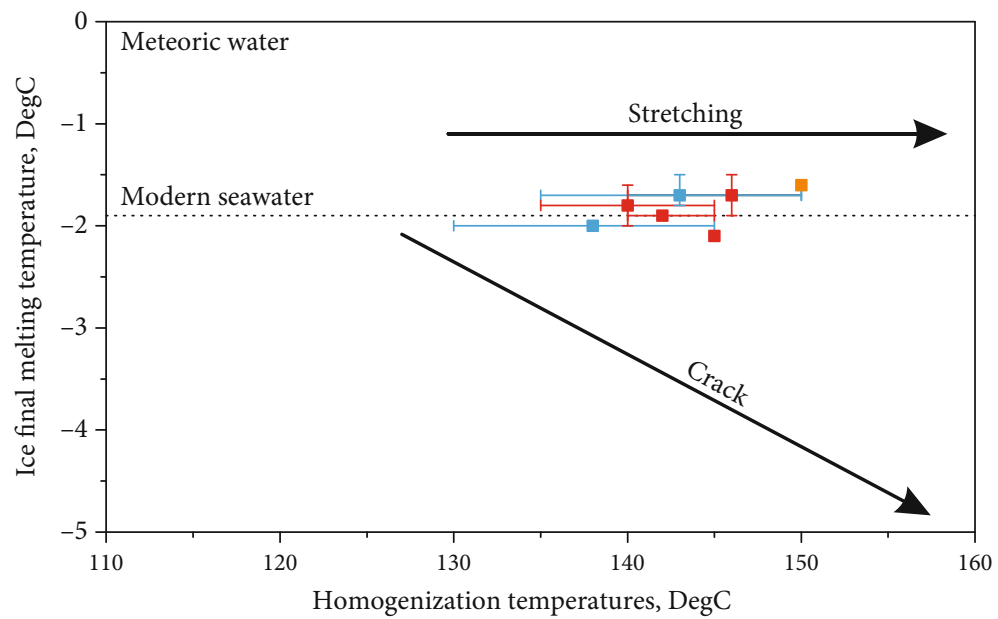

- Aqueous inclusions coexisted with oil inclusions

- Aqueous inclusions coexisted with oil-bearing triphase inclusions

- Aqueous inclusions

FIGURE 6: Relationships between ice-melting temperatures $\left(T_{\mathrm{m}-\mathrm{ice}}\right)$ and homogenization temperatures $\left(T_{\mathrm{h}}\right)$ of aqueous fluid inclusion in CT1.

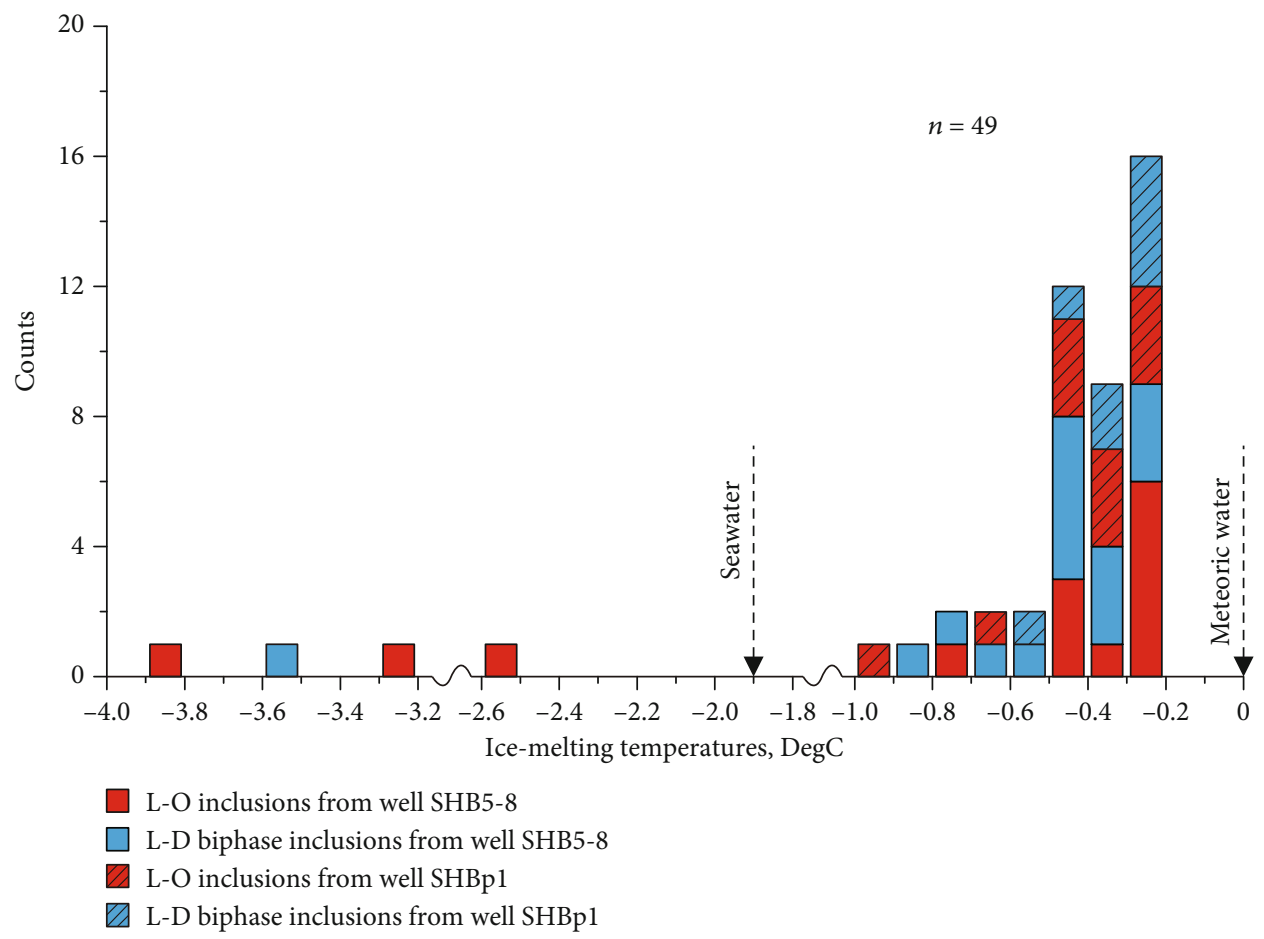

Figure 7: Histograms of ice-melting temperatures of fluid inclusions in CT5 and CTp1-v.

CTp1-v (well SHBp1, west of the Shunbei No. 5 fault zone). Therefore, it indicates that the meteoric fluid may alter the carbonate rock in the Lower-Middle Ordovician succession at the Shunbei No. 5 fault zone and west of the Shunbei No. 5 fault zone.

In the context of tectonic uplift at the end of the Middle Ordovician, the Lower to Middle Ordovician carbonate prone to be altered by meteoric diagenesis due to the subaerial exposure in the study area [46]. The dedolomitization of MD is identified in the well SHBp1 (Figure 3(e)), and the meteoric inclusions are trapped in v-calcite (Figures 3(f) and $3(\mathrm{~g})$ ), which implies that the meteoric diagenesis postdates the dolomitization. Laterally, the evidence of freshwater is recognized in the well SHB5-8 drilling in the fault zone and the well SHBp1 far from the fault. This phenomenon suggests that the occurrence of meteoric diagenesis is not controlled by the distribution of fault system. Overall, lines of evidence indicate the occurrence of meteoric diagenesis in the uplift at end of the Middle Ordovician (Figures 9 and 10). 

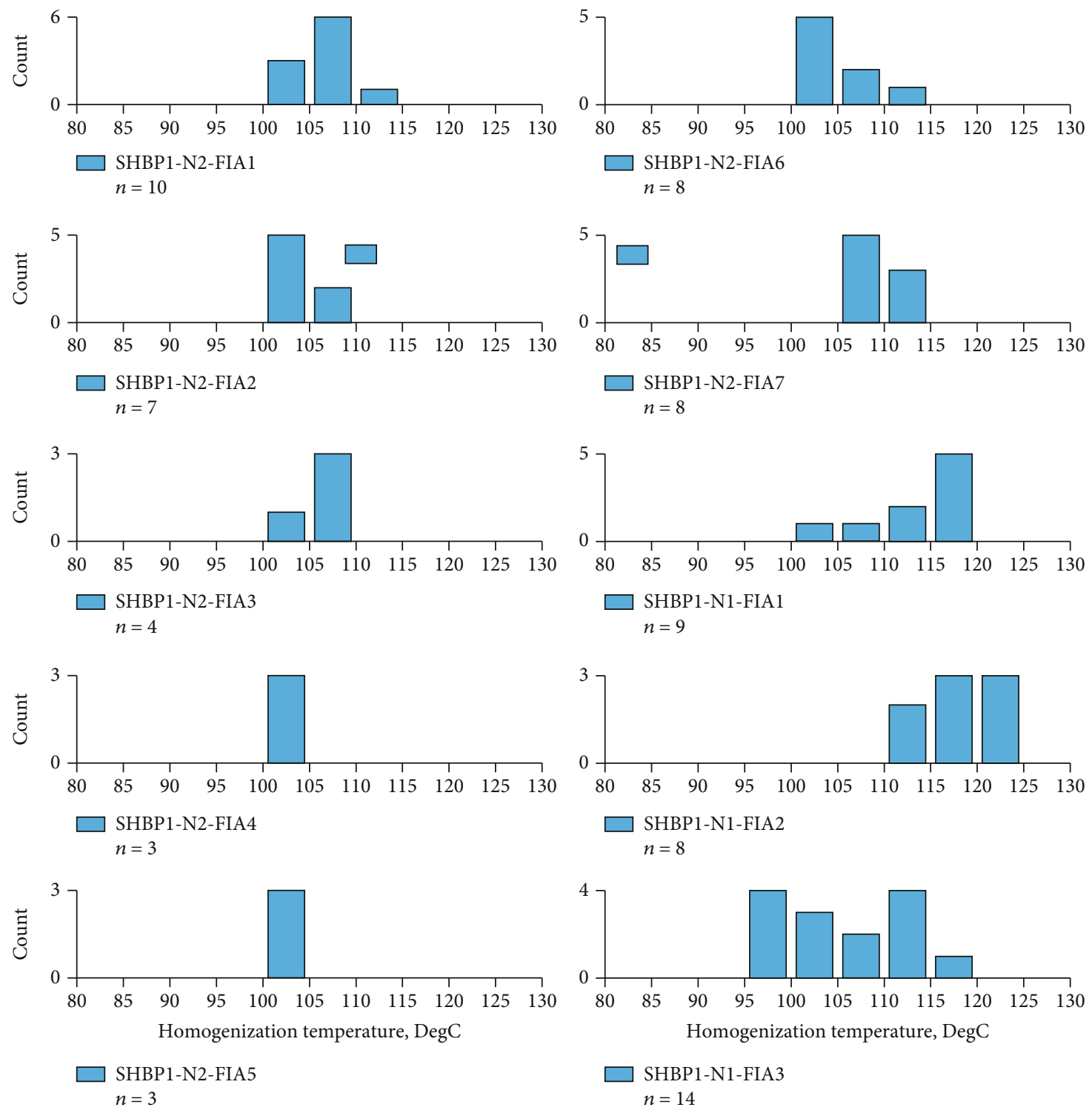

Figure 8: Histograms of homogenization temperatures of fluid inclusions in each FIA in CTp1-f.

6.3. Hydrocarbon Charge History. Petroleum can be trapped in the inclusions when they migrated into carbonate rocks, recording the petroleum charge information, but homogenization temperatures of the biphase oil inclusions may be much lower than their trapping temperatures, due to the flat isochore and complicated composition of oil inclusions [10]. Furthermore, the estimation of the trapping temperatures and pressures of oil inclusions are very difficult because of their small size and complicated compositions [3, 47]. The aqueous inclusions coexisted with petroleum inclusions are commonly applied to estimate the trapping temperatures of the petroleum inclusions. Although the homogenization temperatures of liquid-dominated biphase aqueous inclusions may be lower than the trapping temperatures, the homogenization temperatures of methane-bearing aqueous inclusions coexisting with oil inclusions may be very close to the trapping temperatures $[5,48]$. Therefore, the homogenization temperatures of the aqueous inclusions coexisted with oil inclusions can be applied as the trapping temperatures.

In the Shunbei No. 5 fault zone, liquid-dominated biphase and liquid-only aqueous inclusions, which are interpreted to be trapped in the low-temperatures $\left(<40-50^{\circ} \mathrm{C}\right)$, are coexisted with the liquid-only and liquid-dominated oil inclusions, suggesting that the oil may charge into the Shunbei No. 5 fault zone in low temperatures $\left(<40-50^{\circ} \mathrm{C}\right)$. This indicates that the charging stage of hydrocarbon corresponds to the Shunbei No. 5 fault forming stage which leads to the oil charge (Figures 9 and 10). The evolution history of source rock also correlates to the early-late mature stage [21], which has the potential of oil generation.

In CT1 of the Shunbei No. 1 fault zone, liquid-dominated biphase aqueous inclusions, which are coexisted with liquiddominated biphase oil inclusions, have the $T_{\mathrm{h}}$ value of $130^{\circ} \mathrm{C}$ (inclusions homogenized at $125-130^{\circ} \mathrm{C}$ ). Coupling with the burial-thermal history, charging stage of oil can be correlated 


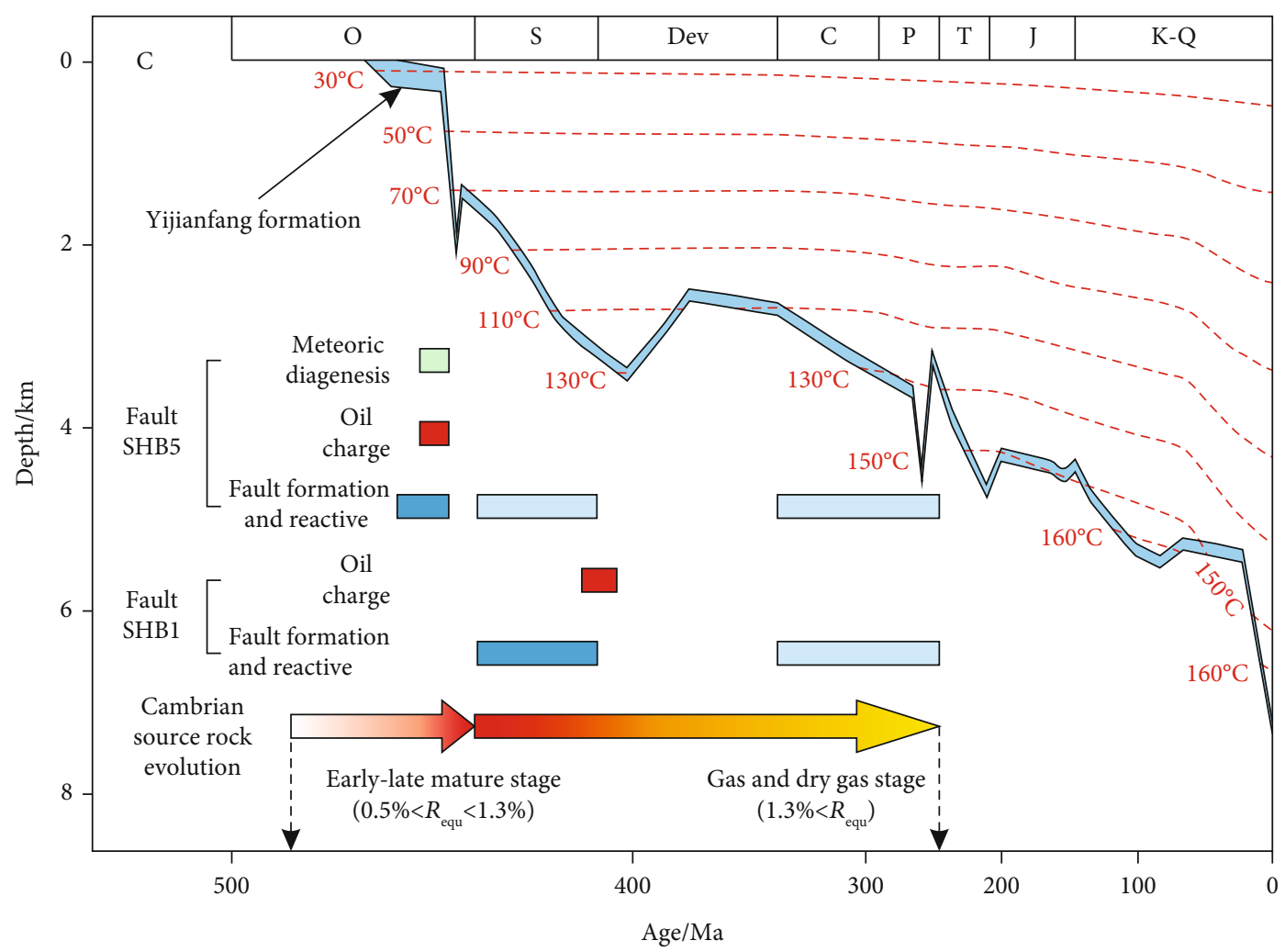

FIGURE 9: The model of oil charge history in the Shunbei No. 5 and No. 1 fault zones. The 1-D burial-thermal history of well SHB1-3 is from Wang et al. [27], and the Cambrian rock evolution is from Qiu et al. [21].

to the Silurian or Carboniferous (Figure 9). The charging stage in the Carboniferous period can be excluded, as Qiu et al. [21] proposed that the source rock had evolved to the generating stage of natural gas during Carboniferous. Therefore, the oil was likely charged during the Silurian that well coupled with the formation of the Shunbei No. 1 fault (Figures 9 and 10).

6.4. Implications for Hydrocarbon Charge. Due to the multistage tectonic movements associating with the complicated diagenetic history in the deeply buried $(>7000 \mathrm{~m})$ reservoirs, minerals generally trapped multistage secondary fluid inclusions and fluid inclusions commonly experienced the reequilibration (e.g., stretching or even crack) impeding the isolation of records of hydrocarbon charging. In this study, we reemphasize the importance of petrographic constraints on the reequilibration and coexistence of aqueous and oil inclusions in deeply buried reservoirs. Based on the systemically petrographic analysis, the convincing evidence for the early-stage charging of hydrocarbon was extracted from fluid inclusion associations in different fault zones.

Faults are generally considered as conduits for the migration of hydrocarbon and diagenetic fluids ([49-51]; [52]), and the fault extension may create secondary porosity in reservoirs, especially in the deep burial carbonate rocks $[13,53]$. As the perspective of petroleum industry, results of fluid inclusions indicate the varied hydrocarbon charging stages in the study area tightly couples with the formation of the faults instead of their reactivation. This also shed light on further exploration of deeply buried hydrocarbon.

\section{Conclusions}

Oil and aqueous fluid inclusions and their assemblages are identified in the calcite cements of the Lower-Middle Ordovician carbonate reservoirs in the Shunbei Oil Field, Tarim Basin. The association of fluid inclusions record the signal of the meteoric fluid and decipher the charging process of hydrocarbon.

Calcite cements in fractures in the Yijianfang Formation of the Shunbei No. 1 fault zone trap secondary inclusions in trails. Those inclusions comprise liquid-dominated biphase aqueous inclusions, liquid-dominated biphase oil inclusions, and/or oil-bearing triphase inclusions. The range of $T_{\mathrm{h}}$ values liquid-dominated biphase aqueous inclusions is $130-$ $150^{\circ} \mathrm{C}$. In contrast, calcite cements in the Yijianfang Formation of the Shunbei No. 5 fault zone trap secondary inclusions in trails, which consist of liquid-only monophase aqueous inclusions, liquid-dominated biphase aqueous inclusions, liquid-dominated biphase oil inclusions, and/or liquid-only monophase oil inclusions.

Calcite cements filling into vugs at the Yingshan Formation of the west of Shunbei No. 5 fault zone trap secondary inclusions in trails, which consist of liquid-only monophase aqueous inclusions and liquid-dominated biphase aqueous inclusions. Vapors of the liquid-only aqueous inclusions do 


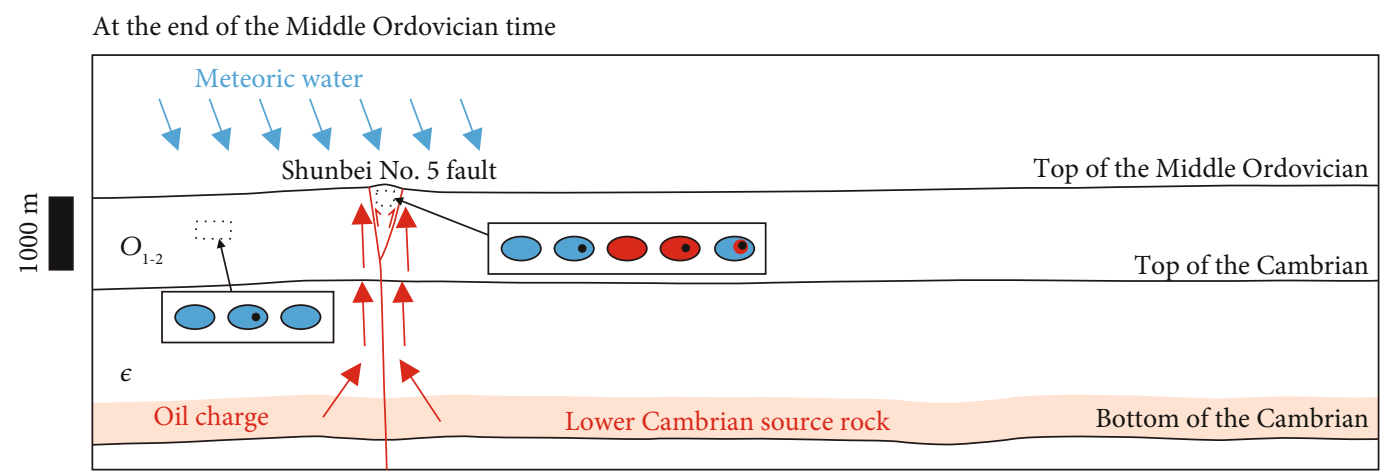

(a)

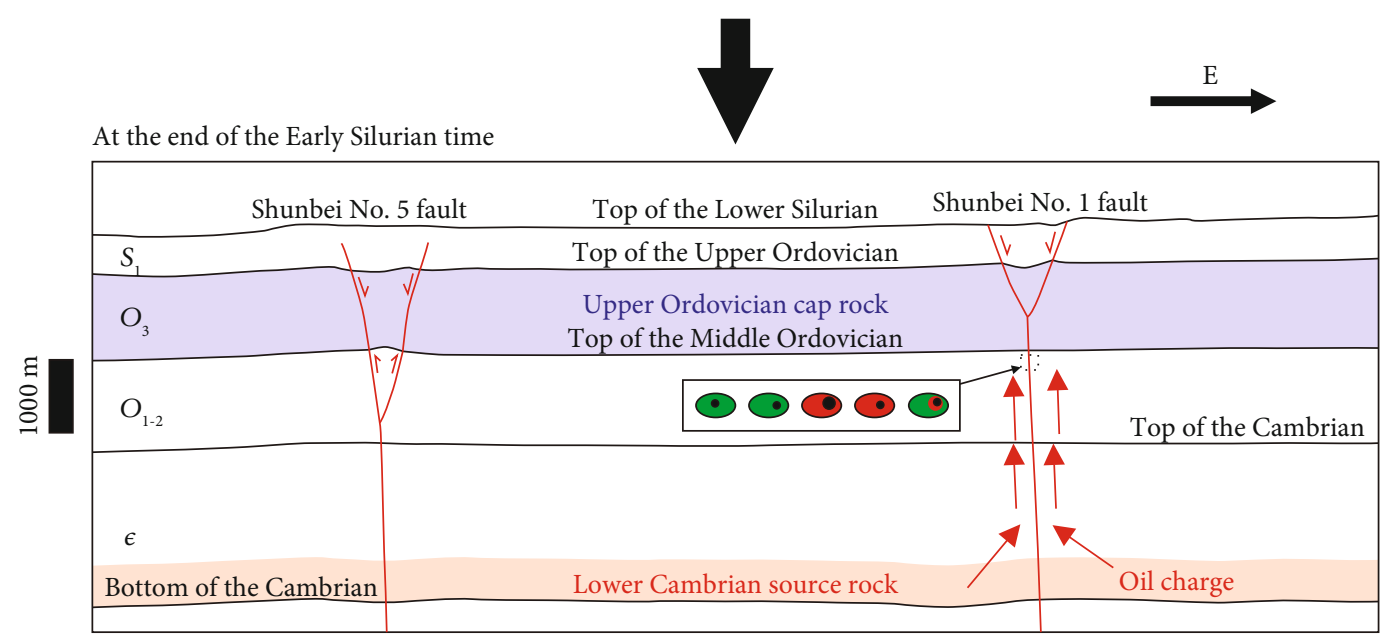

(b)
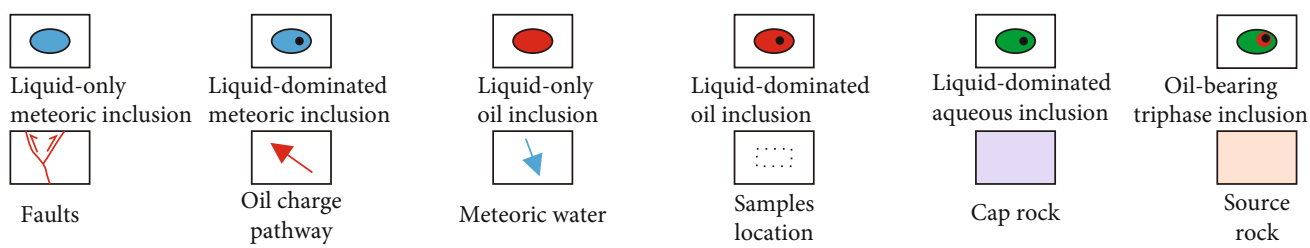

Figure 10: The model of oil charging history in the Shunbei No. 5 and No. 1 fault zones revised from the seismic section in Deng et al. [14]. The scale bar for depths is estimated from the thickness of the Ordovician strata (with a thickness of approximately $1500 \mathrm{~m}$ ).

not appear during supercooling. This indicates that the aqueous inclusions record the meteoric fluid with low salinities and are trapped in a low-temperature environment.

Based on the burial-thermal history and the Cambrian source rock evolution, the charging stage of hydrocarbon in the Shunbei No. 5 fault zone corresponds to the end of the Middle Ordovician. In the context of the burial-thermal history and the Cambrian source rock evolution, the charging stage of oil can be interpreted in the Silurian. Overall, the evolution of fault system dominates the charging process of hydrocarbon in the deeply buried reservoirs at the Tarim Basin.

\section{Data Availability}

The data can be found in the Supplementary Information files which we will upload with our manuscript.

\section{Conflicts of Interest}

We declare that we have no financial and personal relationships with other people or organizations that can inappropriately influence our work, and there is no professional or other personal interest of any nature or kind in any product, service, and/or company that could be construed as influencing the position presented in, or the review of, the manuscript entitled "Fluid inclusions record hydrocarbon charge history in the Shunbei Area, Tarim Basin, NW China".

\section{Acknowledgments}

This research was supported by financial support from the Young Scholars Development Fund of the Southwest Petroleum University given to Ziye Lu (No. 201899010102), Sichuan Province Key Laboratory of Natural Gas Geology (No. 2018trqdz03), the National Science and Technology 
Major Project (No. 2017ZX05005-001-010), and the National Natural Science Foundation of China (No. 41902239). Comments and suggestions from four anonymous reviewers considerably improved the manuscript.

\section{Supplementary Materials}

Supplementary 1. ESM 1: petrographic photos showing FIAs (fluid inclusion assemblages) in CT1 and CT5, and they support the coexistence of oil and aqueous inclusions which are measured in Figures 5-7.

Supplementary 2. ESM 2: detailed microthermometric data of aqueous inclusions in CT1 and CTp1-f.

Supplementary 3. ESM 3: detailed microthermometric data of aqueous inclusions in CT5 and CTp1-v.

\section{References}

[1] J. Conliffe, E. Burden, and D. Wilton, "The use of integrated fluid inclusion studies for constraining petroleum charge history at Parsons Pond, Western Newfoundland, Canada," Minerals, vol. 7, no. 3, pp. 39-58, 2017.

[2] R. H. Goldstein and T. Reynolds, Systematics of Fluid Inclusions in Diagenetic Minerals: SEPM Short Course Notes 31, Society for Sedimentary Geology, USA, 1986.

[3] D. H. Liu, X. M. Xiao, J. K. Mi et al., "Determination of trapping pressure and temperature of petroleum inclusions using PVT simulation software-a case study of Lower Ordovician carbonates from the Lunnan Low Uplift, Tarim Basin," Marine and Petroleum Geology, vol. 20, no. 1, pp. 29-43, 2003.

[4] Z. Y. Lu, H. H. Chen, H. R. Qing et al., "Petrography, fluid inclusion and isotope studies in Ordovician carbonate reservoirs in the Shunnan area, Tarim basin, NW China: implications for the nature and timing of silicification," Sedimentary Geology, vol. 359, pp. 29-43, 2017.

[5] H. W. Ping, H. H. Chen, and G. H. Jia, "Petroleum accumulation in the deeply buried reservoirs in the northern Dongying Depression, Bohai Bay Basin, China: new insights from fluid inclusions, natural gas geochemistry, and 1-D basin modeling," Marine and Petroleum Geology, vol. 80, pp. 70-93, 2017.

[6] C. Rossi, R. H. Goldstein, A. Ceriani, and R. Marfil, "Fluid inclusions record thermal and fluid evolution in reservoir sandstones, Khatatba Formation, Western Desert, Egypt: a case for fluid injection," AAPG Bulletin, vol. 86, pp. 17731799, 2002.

[7] R. H. Goldstein, "Fluid inclusions in sedimentary and diagenetic systems," Lithos, vol. 55, no. 1-4, pp. 159-193, 2001.

[8] R. H. Goldstein, "Fluid inclusion geothermometry in sedimentary systems: from paleoclimate to hydrothermal," in Thermal History Analysis of Sedimentary Basins: Methods and Case Hitories, N. Harris and K. E. Peters, Eds., vol. 103, pp. 45-63, SEPM special publication, 2012.

[9] A. M. V. D. Kerkhof and U. F. Hein, "Fluid inclusion petrography," Lithos, vol. 55, no. 1-4, pp. 27-47, 2001.

[10] I. A. Munz, "Petroleum inclusions in sedimentary basins: systematics, analytical methods and applications," Lithos, vol. 55, no. 1-4, pp. 195-212, 2001.

[11] J. Bourdet, J. Pironon, G. Levresse, and J. Tritlla, "Petroleum type determination through homogenization temperature and vapour volume fraction measurements in fluid inclusions," Geofluids, vol. 8, no. 1, pp. 46-59, 2008.

[12] J. Bourdet, J. Pironon, G. Levresse, and J. Tritlla, "Petroleum accumulation and leakage in a deeply buried carbonate reservoir, Níspero field (Mexico)," Marine and Petroleum Geology, vol. 27, no. 1, pp. 126-142, 2010.

[13] Y. T. Li, L. X. Qi, S. N. Zhang et al., "Characteristics and development mode of the Middle and Lower Ordovician fault-karst reservoir in Shunbei area," Acta Petrolei Sinica, vol. 40, no. 12, pp. 1470-1484, 2019.

[14] S. Deng, H. L. Li, Z. P. Zhang, X. Wu, and J. B. Zhang, "Characteristics of differential activities in major strike-slip fault zones and their control on hydrocarbon enrichment in Shunbei area and its surroundings," Oil \& Gas Geology, vol. 39, no. 5, pp. 878-888, 2018.

[15] Y. W. Wang, H. H. Chen, H. F. Guo et al., "Hydrocarbon charging history of the ultra-deep reservoir in Shun 1 strikeslip fault zone," Oil \& Gas Geology, vol. 40, no. 5, pp. 972989, 2019.

[16] J. Chang, N. S. Qiu, and W. Xu, “Thermal regime of the Tarim Basin, Northwest China: a review," International Geology Review, vol. 59, no. 1, pp. 45-61, 2016.

[17] S. Deng, H. L. Li, J. Han, D. Y. Cui, and R. Zou, "Characteristics of the central segment of Shunbei 5 strike-slip fault zone in Tarim Basin and its geological significance," Oil \& Gas Geology, vol. 40, no. 5, pp. 990-998, 2019.

[18] S. Deng, H. L. Li, Z. P. Zhang, J. B. Zhang, and X. Yang, "Structural characterization of intracratonic strike-slip faults in the central Tarim Basin," AAPG Bulletin, vol. 103, no. 1, pp. 109-137, 2019.

[19] X. G. Gao, X. Wu, C. J. Hong, and S. S. Wen, "Geochemical characteristics of Ordovician oil in the Shunbei 1 fault," Petroleum Geology and Engineering, vol. 32, no. 6, pp. 37-40, 2018.

[20] M. X. Luo, Y. T. Xia, X. M. Shao, and X. Wu, "Geochemical characteristics and origin of oil from different strata in Shunbei oil and gas field," Petroleum Geology \& Experiment, vol. 41, no. 6, pp. 849-855, 2019.

[21] N. S. Qiu, J. Chang, Y. H. Zuo, J. Y. Wang, and H. L. Li, “Thermal evolution and maturation of lower Paleozoic source rocks in the Tarim Basin, northwest China," AAPG Bulletin, vol. 96, no. 5, pp. 789-821, 2012.

[22] Z. Q. Xu, S. T. Li, J. X. Zhang et al., "Paleo-Asian and Tethyan tectonic systems with docking the Tarim block," Acta Petrologica Sinica, vol. 27, no. 1, pp. 1-22, 2011.

[23] C. L. Zhang, H. B. Zou, H. K. Li, and H. Y. Wang, “Tectonic framework and evolution of the Tarim Block in NW China," Gondwana Research, vol. 23, no. 4, pp. 1306-1315, 2013.

[24] F. Z. Jiao, "Significance and prospect of ultra-deep carbonate fault-karst reservoirs in Shunbei area," Oil \& Gas Geology, vol. 39, no. 2, pp. 207-216, 2018.

[25] A. Ma, Z. Jin, H. Li et al., "Secondary alteration and preservation of ultra-deep Ordovician oil reservoirs of north Shuntuoguole area of Tarim basin, NW China," Earth Science, vol. 45, no. 5, pp. 1737-1752, 2020.

[26] H. Liu, I. D. Somerville, C. S. Lin, and S. J. Zuo, "Distribution of Palaeozoic tectonic superimposed unconformities in the Tarim Basin, NW China: significance for the evolution of palaeogeomorphology and sedimentary response," Geological Journal, vol. 51, no. 4, pp. 627-651, 2016.

[27] Y. X. Wang, Y. Gu, Q. Fu, B. Wang, Y. L. Wan, and Y. T. Li, "Characteristics and genesis of deep carbonate reservoirs in 
Shunbei area," Journal of Jilin University (Earth Science Edition), vol. 49, no. 4, pp. 932-946, 2019.

[28] X. Y. Han, S. Deng, L. J. Tang, and Z. C. Cao, “Geometry, kinematics and displacement characteristics of strike-slip faults in the northern slope of Tazhong uplift in Tarim Basin: a study based on 3D seismic data," Marine and Petroleum Geology, vol. 88, pp. 410-427, 2017.

[29] C. Huang, "Multi-stage activity characteristics of small-scale strike-slip faults in superimposed basin and its identification method: a case study of Shunbei area," Petroleum Geology \& Experiment, vol. 41, no. 3, pp. 379-389, 2019.

[30] Y. C. Liu, N. S. Qiu, H. L. Li, A. L. Ma, J. Chang, and J. K. Jia, "Terrestrial heat flow and crustal thermal structure in the northern slope of Tazhong uplift in Tarim Basin," Geochermics, vol. 83, pp. 0375-6505, 2020.

[31] H. L. Li, N. S. Qiu, and Z. J. Jin, "Thermal history of central area of the tarim basin by apatite fission track analysis," Chinese Journal of Geology, vol. 40, no. 1, pp. 129-132, 2005.

[32] R. J. Bodnar, "Revised equation and table for determining the freezing-point depression of $\mathrm{H}_{2} \mathrm{O}-\mathrm{NaCl}$ solutions," Geochimica et Cosmochimica Acta, vol. 57, no. 3, pp. 683-684, 1993.

[33] G. X. Chi and P. Ni, "Equations for calculation of $\mathrm{NaCl} /(\mathrm{NaCl}$ $\left.+\mathrm{CaCl}_{2}\right)$ ratios and salinities from hydrohalite-melting and ice-melting temperatures in the $\mathrm{H}_{2} \mathrm{O}-\mathrm{NaCl}-\mathrm{CaCl}_{2}$ system," Acta Petrologica Sinica, vol. 23, no. 1, pp. 33-37, 2007.

[34] M. Steele-Mac Innis, R. J. Bodnar, and J. Naden, "Numerical model to determine the composition of $\mathrm{H}_{2} \mathrm{O}-\mathrm{NaCl}-\mathrm{CaCl}_{2}$ fluid inclusions based on microthermometric and microanalytical data," Geochimica et Cosmochimica Acta, vol. 75, no. 1, pp. 21-40, 2011.

[35] C. E. Barker and R. H. Goldstein, "Fluid-inclusion technique for determining maximum temperature in calcite and its comparison to the vitrinite reflectance geothermometer," Geology, vol. 18, no. 10, pp. 1003-1006, 1990.

[36] R. J. Bodnar, "Reequilibration of fluid inclusions," in Fluid Inclusions: Analysis and Interpretation, S. A. Anderson and D. Marshall, Eds., vol. 32, pp. 213-230, Mineral Association, Canada,, 2003.

[37] R. H. Goldstein, "Reequilibration of fluid inclusions in lowtemperature calcium-carbonate cement," Geology, vol. 14, no. 9, pp. 792-795, 1986.

[38] D. R. Prezbindowski, "Experimental stretching of fluid inclusions in calcite - implications for diagenetic studies," Geology, vol. 15, no. 4, pp. 333-336, 1987.

[39] K. Ujiie, A. Yamaguchi, and S. Taguchi, "Stretching of fluid inclusions in calcite as an indicator of frictional heating on faults," Geology, vol. 36, no. 2, pp. 111-114, 2008.

[40] G. X. Chi and H. Z. Lu, "Validation and representation of fluid inclusion microthermometric data using the fluid inclusion assemblage (FIA) concept," Acta Petrologica Sinica, vol. 24, no. 9, pp. 1945-1953, 2008.

[41] E. Roedder and R. J. Bodnar, "Geologic pressure determination from fluid inclusion studies," Annual Review of Earth and Planetary Sciences, vol. 8, no. 1, pp. 263-301, 1980.

[42] W. J. Johnsom and R. H. Goldstein, “Cambrian sea water preserved as inclusions in marine low-magnesium calcite cement," Nature, vol. 362, no. 6418, pp. 335-337, 1993.

[43] J. J. Wilkinson, "Metastable freezing: a new method for the estimation of salinity in aqueous fluid inclusions," Economic Geology, vol. 112, no. 1, pp. 185-193, 2017.
[44] L. Jiang, W. Pan, C. Cai et al., "Fluid mixing induced by hydrothermal activity in the ordovician carbonates in Tarim Basin, China," Geofluids, vol. 15, no. 3, pp. 483-498, 2015.

[45] Z. Q. Li, R. H. Goldstein, and E. K. Franseen, "Meteoric calcite cementation: diagenetic response to relative fall in sea-level and effect on porosity and permeability, Las Negras area, southeastern Spain," Sedimentary Geology, vol. 348, pp. 1-18, 2017.

[46] Q. Q. Wu, J. R. Li, F. Cao et al., "Characteristics of fault-karst carbonate reservoirs in the Shunbei No. 1 well block, Tarim Basin," Carsologica Sinica, vol. 38, no. 6, pp. 444-449, 2019.

[47] J. Pironon, R. Thiery, M. Ayt Ougougdal, S. Teinturier, G. Beaudoin, and F. Walgenwitz, "FT-IR measurements of petroleum fluid inclusions: methane, n-alkanes and carbon dioxide quantitative analysis," Geofluids, vol. 1, no. 1, pp. $2-$ 10, 2001.

[48] J. S. Hanor, "Dissolved methane in sedimentary brines; potential effect on the PVT properties of fluid inclusions," Economic Geology, vol. 75, no. 4, pp. 603-609, 1980.

[49] P. Eichhubl, N. C. Davatzes, and S. P. Becker, "Structural and diagenetic control of fluid migration and cementation along the Moab fault, Utah," AAPG Bulletin, vol. 93, no. 5, pp. 653-681, 2009.

[50] P. Hennings, P. Allwardt, P. Paul et al., "Relationship between fractures, fault zones, stress, and reservoir productivity in the Suban gas field, Sumatra, Indonesia," AAPG Bulletin, vol. 96, no. 4, pp. 753-772, 2012.

[51] B. R. Ilg, S. Hemmings-Sykes, A. Nicol et al., "Normal faults and gas migration in an active plate boundary, southern Taranaki Basin, offshore New Zealand," AAPG Bulletin, vol. 96, no. 9, pp. 1733-1756, 2012.

[52] D. A. Ferrill, M. A. Evans, R. N. McGinnis et al., "Fault zone processes and fluid history in Austin Chalk, southwest Texas," AAPG Bulletin, vol. 104, no. 2, pp. 245-283, 2020.

[53] S. N. Ehrenberg, O. Walderhaug, and K. Bjørlykke, "Carbonate porosity creation by mesogenetic dissolution: reality or illusion?," AAPG Bulletin, vol. 96, no. 2, pp. 217-233, 2012. 